\title{
The Mothball, Sustainment, and Proposed Reactivation of the Hypersonic Tunnel Facility (HTF) at NASA Glenn Research Center Plum Brook Station
}

Scott R. Thomas and Jinho Lee

Glenn Research Center, Cleveland, Ohio

John W. Stephens, Robert W. Hostler, Jr., and William D. Von Kamp

Plum Brook Operations Support Group, Sandusky, Ohio 


\section{NASA STI Program . . . in Profile}

Since its founding, NASA has been dedicated to the advancement of aeronautics and space science. The NASA Scientific and Technical Information (STI) program plays a key part in helping NASA maintain this important role.

The NASA STI Program operates under the auspices of the Agency Chief Information Officer. It collects, organizes, provides for archiving, and disseminates NASA's STI. The NASA STI program provides access to the NASA Aeronautics and Space Database and its public interface, the NASA Technical Reports Server, thus providing one of the largest collections of aeronautical and space science STI in the world. Results are published in both non-NASA channels and by NASA in the NASA STI Report Series, which includes the following report types:

- TECHNICAL PUBLICATION. Reports of completed research or a major significant phase of research that present the results of NASA programs and include extensive data or theoretical analysis. Includes compilations of significant scientific and technical data and information deemed to be of continuing reference value. NASA counterpart of peer-reviewed formal professional papers but has less stringent limitations on manuscript length and extent of graphic presentations.

- TECHNICAL MEMORANDUM. Scientific and technical findings that are preliminary or of specialized interest, e.g., quick release reports, working papers, and bibliographies that contain minimal annotation. Does not contain extensive analysis.

- CONTRACTOR REPORT. Scientific and technical findings by NASA-sponsored contractors and grantees.
- CONFERENCE PUBLICATION. Collected papers from scientific and technical conferences, symposia, seminars, or other meetings sponsored or cosponsored by NASA.

- SPECIAL PUBLICATION. Scientific, technical, or historical information from NASA programs, projects, and missions, often concerned with subjects having substantial public interest.

- TECHNICAL TRANSLATION. Englishlanguage translations of foreign scientific and technical material pertinent to NASA's mission.

Specialized services also include creating custom thesauri, building customized databases, organizing and publishing research results.

For more information about the NASA STI program, see the following:

- Access the NASA STI program home page at http://www.sti.nasa.gov

- E-mail your question via the Internet to help@ sti.nasa.gov

- Fax your question to the NASA STI Help Desk at 443-757-5803

- Telephone the NASA STI Help Desk at 443-757-5802

- Write to: NASA Center for AeroSpace Information (CASI) 7115 Standard Drive Hanover, MD 21076-1320 
NASA/TM-2010-216936

AIAA-2010-4533

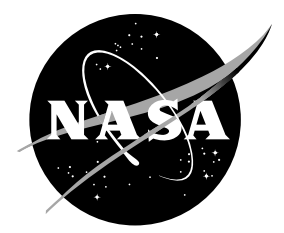

\section{The Mothball, Sustainment, and Proposed Reactivation of the Hypersonic Tunnel \\ Facility (HTF) at NASA Glenn Research Center Plum Brook Station}

Scott R. Thomas and Jinho Lee

Glenn Research Center, Cleveland, Ohio

John W. Stephens, Robert W. Hostler, Jr., and William D. Von Kamp

Plum Brook Operations Support Group, Sandusky, Ohio

Prepared for the

27th Aerodynamic Measurement Technology and Ground Testing Conference

sponsored by the American Institute of Aeronautics and Astronautics

Chicago, Illinois, June 28 to July 1, 2010

National Aeronautics and

Space Administration

Glenn Research Center

Cleveland, Ohio 44135 
Trade names and trademarks are used in this report for identification only. Their usage does not constitute an official endorsement, either expressed or implied, by the National Aeronautics and Space Administration.

This work was sponsored by the Fundamental Aeronautics Program at the NASA Glenn Research Center.

Level of Review: This material has been technically reviewed by technical management.

Available from

NASA Center for Aerospace Information 7115 Standard Drive

Hanover, MD 21076-1320
National Technical Information Service 5301 Shawnee Road Alexandria, VA 22312

Available electronically at http://gltrs.grc.nasa.gov 


\title{
The Mothball, Sustainment, and Proposed Reactivation of the Hypersonic Tunnel Facility (HTF) at NASA Glenn Research Center Plum Brook Station
}

\author{
Scott R. Thomas and Jinho Lee \\ National Aeronautics and Space Administration \\ Glenn Research Center \\ Cleveland, Ohio 44135 \\ John W. Stephens, Robert W. Hostler, Jr., and William D. Von Kamp \\ Plum Brook Operations Support Group \\ Sandusky, Ohio 44870
}

\begin{abstract}
The Hypersonic Tunnel Facility (HTF) located at the NASA Glenn Research Center's Plum Brook Station in Sandusky, Ohio, is the nation's only large-scale, non-vitiated, hypersonic propulsion test facility. The HTF, with its 4-story graphite induction heater, is capable of duplicating Mach 5, 6, and 7 flight conditions. This unique propulsion system test facility has experienced several standby and reactivation cycles. The intent of the paper is to overview the HTF capabilities to the propulsion community, present the current status of HTF, and share the lessons learned from putting a large-scale facility into mothball status for a later restart.
\end{abstract}

\section{Introduction}

The NASA Glenn Research Center Hypersonic Tunnel Facility (HTF) is one of four large-scale test facilities located on the 6400 acre campus of Plum Brook Station in Sandusky, Ohio. The HTF is a largescale, government-controlled property which is remotely located with large exclusion zones that are ideal for safely testing propulsion systems at the extreme conditions typical of hypersonic flight. The HTF is a blow-down, non-vitiated, free-jet facility capable of simulating up to Mach 7 flight conditions where the stagnation temperatures reach up to $3500{ }^{\circ} \mathrm{F}$. The HTF is unique because the synthetic air generation process provides the enthalpy required for up to Mach 7 simulation with non-vitiated flow. Major features of the HTF are shown in Figure 1 and an aerial view in Figure 2.

Central to the facility's unique method of manufacturing synthetic air is an inductively-heated, graphite-core storage heater. During typical facility operation, the graphite-core storage heater is systematically brought up to the required operating temperature (up to $4000^{\circ} \mathrm{F}$ ) using electrically powered induction coils. Once at temperature, gaseous nitrogen is passed through the heater. After heating, this hot nitrogen gas is mixed with unheated nitrogen and oxygen in the correct proportion to simulate air at the desired enthalpy. The facility can deliver this synthetic air at up to $220 \mathrm{lb} / \mathrm{sec}$.

The HTF was originally configured and has been utilized in a free-jet test mode. Three water-cooled, axisymmetric free-jet nozzles are available with exit Mach numbers of 5, 6, and 7. Each nozzle has a 42-in. diameter exit plane, and provides high-quality, free-jet flow into the test chamber. In 2006, a directconnect testing mode was added to the facility which included the capability to accurately measure and deliver synthetic air flows down to approximately $50 \mathrm{lb} / \mathrm{s}$. The free-jet and direct-connect hardware both utilize the same ancillary facility systems, therefore, minimizing the time required to change between the two operating modes.

The free-jet facility nozzles and the HTF test chamber can accommodate models up to $12 \mathrm{ft}$. in length and up to $2 \mathrm{ft}$. in diameter. The facility's graphite induction heater can supply nitrogen flows, up to $130 \mathrm{lb} / \mathrm{s}$ at $4000{ }^{\circ} \mathrm{F}$ and $1200 \mathrm{psia}$. Gaseous nitrogen is supplied from the 5000 psia, 750,000 standard 
cubic feet (scf) railcar shown in Figure 3. Hot nitrogen from the heater flows through graphite-lined, water-cooled piping, through the Radiation Shutter Valve (used to isolate the test cabin from the hot graphite heater), and into a water-cooled mixer. The Radiation Shutter Valve seals off the storage heater between test runs, allowing a positive pressure nitrogen or helium purge to be maintained on the heater. In the mixer section, oxygen and diluent nitrogen for temperature control are mixed with the hot nitrogen to produce a test condition with true temperature, composition, and altitude simulation. Ambient gaseous oxygen is supplied from the array of six vessels shown in Figure 4. A steam ejector system with a flow of $540 \mathrm{lb} / \mathrm{s}$ of $150 \mathrm{psig}$ saturated steam provides the appropriate altitude condition in the test cell. The altitude limit is approximately $120,000 \mathrm{ft}$. Typical run times vary with test condition and typically range from 1 to $5 \mathrm{~min}$. The facility hot train is shown in Figure 5. One of the free-jet nozzles is shown in Figure 6.

Several major test programs were conducted in the HTF since it was built and configured as a hypersonic aero-propulsion facility. The Hypersonic Research Engine (HRE) was tested at Mach 5, 6, and 7 from 1972 to 1974 (Ref. 1). The HRE program was one of the earliest demonstrations of scramjet performance in a ground-based facility. In 1974, following the HRE program, the HTF was mothballed along with the majority of the facilities at the NASA GRC Plum Brook Station. Documentation of inspections from that time show the facility, when put into a mothball status, was already in need of repair and refurbishment following extensive use during the HRE program.

A decision to reactivate HTF was made in the late 1980s. From 1990 to 1994 the facility was restored and a series of integrated systems tests (ISTs) were conducted in 1994 and 1995 (Ref. 2). This reactivation effort brought the graphite heater and all other facility systems back to a fully operational status.

A propulsion test of the Strutjet Engine, a Rocket-Based Combined Cycle (RBCC) engine system, was conducted in 1996 (Ref. 3). The Strutjet engine is a ram/scram combustor with integrated rocket thrusters. Originally the testing was planned using both hydrocarbon (JP-10) and then also hypergolic fuels. Forty-one tests of the engine were completed using JP-10 fuel before this activity ended abruptly with a failure of the Radiation Shutter Valve.

The facility, including the graphite heater, was rebuilt and restored from 1997 to 2000 (Ref. 4). The failure in 1996 of the Radiation Shutter Valve had resulted in substantial facility damage, necessitating the restoration project. This project was completed late 1999, culminating in another series of IST's in early 2000. Over the two and a half year rehabilitation effort, significant improvements were implemented at the HTF to improve productivity and reliability, as well as to ensure personnel safety.

In 2002, testing of a Department of Energy (DOE) Reheater Combustor concept was conducted at HTF. The test did not require the graphite heater, but took advantage of many of the ancillary facility systems. The free-jet hardware was stored locally while the chamber and gas systems were modified and utilized for the DOE test program. Following the program, the facility was restored to the free-jet configuration.

In 2003, HTF was selected to test a large-scale Rocket-Based Combined Cycle (RBCC) directconnect combustor experiment for the NASA Next Generation Launch Technology (NGLT) program's Integrated System Test of an Air Breathing Rocket (ISTAR) Project (Ref. 5). From 2004 to 2006 significant facility enhancements, including the conversion to the direct-connect operating mode, were completed in preparation for this test. A major upgrade was made to the facility fuel capability with the addition of an endothermic hydrocarbon fuel reactor and supporting equipment capable of simulating the heated and cracked fuel conditions of RBCC engine environments. This effort included the addition of a $6 \mathrm{MW}$ substation, new steam generators to replace the World War 2 vintage boilers, and modernization of the flow control computer. The free-jet hardware (nozzles and aerodynamic appliances) were removed and stored locally to make room for installation of the direct-connect hardware. The direct-connect hardware included an adaptive nozzle, a calorimeter duct, necessary transition hardware, and a test article simulator for IST runs. 
In 2006 the NGLT program and ISTAR project were cancelled and this test was never conducted. Cancellation of the NGLT program resulted in a limited national hypersonic testing requirement. This led to the decision in 2007 by the NASA Aeronautics Research Mission Directorate (ARMD) along with the Aeronautics Test Program (ATP) to conduct an orderly shutdown and mothball of the HTF and associated assets.

The main focus of this paper is to describe the following: 1) how the HTF mothball task was implemented to preserve and protect the facility for future use, 2) on-going efforts underway to monitor and maintain the facility to prevent deterioration of vital assets, and 3) the scope of work required for reactivation of the facility. Currently, the HTF heater and high-pressure supply systems are in excellent condition. A nominal level of effort, similar to that of any other large-scale facility, would be required to return HTF to an operational status. However, if the facility remains in mothball status a long period of time there will be additional challenges involved.

\section{Mothball of the Hypersonic Tunnel Facility}

\section{Background}

A carefully thought-out mothball plan was prepared and executed by the test team at Plum Brook Station in order to minimize the level of effort required by future programs to reactivate the facility. Much of the experience necessary to put the facility into a mothball status was already in place at Plum Brook Station from the 1974 shutdown. The lessons-learned from this experience were leveraged as the basis of the current mothball activity. The crew worked with the realization that controlled air breathing hypersonic flight is the final frontier in aeronautical sciences and will, again, become a national priority. Therefore, every effort was made to safe guard the facility and its assets for future use. Such facilities are at higher risk for extended down times, as was experienced even at HTF following the Radiation Shutter Valve failure in 1996. It was also recognized by NASA that the cadre of facilities comparable to HTF is extremely limited. In addition, as a nation, it may not make fiscal sense to build a new facility with this type of capability in the time frame generally required (at least in recent history) to support high priority national hypersonic initiatives. Therefore, mothballing and preserving HTF was, and still is, in the best interest for the nation.

\section{Planning of Mothball Task}

The mothball of the Hypersonic Tunnel Facility was planned and completed in calendar year 2007. The Plum Brook team developed a plan and executed an orderly shutdown of the facility, where much of the 1974 lessons-learned information was incorporated to preserve this capability for the future. The current mothball process assumed that the facility would be in a mothball status for a 10 year period or longer. The team used NASA Procedural Requirements, NPR 8800.15A, Chapter 3.9.4 (see Appendix A) as the primary basis for this process.

\section{Elements of the Mothball Task}

Tasks performed to put HTF into a mothball status are summarized in this section. It was assumed that the facility would be in this status for a period of ten years and that the essential systems would be preserved or put into protective storage. It was also assumed that there would be some level of sustainment activity following the completion of the mothball task in order to provide periodic inspections as well as maintenance, as needed. In addition it was recognized that key personal from the current facility team may not be available to support future reactivation and operation of HTF or that the current personal would be so far removed from HTF such that retraining in the facility systems would be 
required prior to any future testing. Therefore, the current mothball activities included archival documentation elements that will help with future facility endeavors. These assumptions lead the following activities to protect and to preserve the essential HTF assets.

1) Weather-protected facility and buildings: All lower windows were covered with painted plywood to protect the glass and provide additional security. The upper windows were sealed and screens were checked and repaired. Screens, netting, and sealant were used to protect against weather and prevent pests from entering the facility. All penetrations into the buildings were sealed including open pipes, vents, the ejector, and entrance ways. The exterior sluice was defoliated and cleared of sediment and debris. Ditches were re-graded to insure proper drainage. The outside terminal boxes were cleaned and all seals were verified.

2) Cleanliness maintained in the vital systems: Preservation of the HTF induction heater and the gaseous oxygen system (vessels and piping) was a priority during the mothballing of HTF. A flow through purge system was designed to supply low pressure gaseous nitrogen to the induction heater and the gaseous oxygen system. Nitrogen gas can be supplied from either a tube trailer or the nitrogen railcar. The system receives the full pressure from the supply source (up to $2400 \mathrm{psig}$ from a tube trailer or up to $4200 \mathrm{psig}$ from the railcar) and reduces pressure to the desired level. The oxygen system is purged at a delivery pressure up to 25 psig, with 5 psig nominal. This reduction station includes a back pressure regulator and pressure relief valve. The back pressure regulator allows a soft venting of the system and vessels when the system is exposed to heating during periods of high solar exposure. The graphite induction heater is purged at a nominal pressure of $10 \mathrm{in}$. of water column. This purge system was extensively tested to assure very minimal leakage would occur in the future from both the heater vessel and the gaseous oxygen system.

The Radiation Shutter Valve was hydraulically moved to the open position and locked into place. A bypass system was put in place around this valve to ensure that it would not be over pressurized by the flow through purge system. The high-pressure relief valve on the graphite heater was removed and stored. The line was blanked to eliminate leaks and contamination.

3) Water pipes and tanks: The cooling systems were drained to prevent damage to the systems from extended periods of extreme cold and from contamination. The HTF cooling system consists of a 20,000 gal storage tank shown in Figure 7 used in the low pressure cooling of the heater, Radiation Shutter Valve and portions of the synthetic air delivery system (Hot Train). The three 6,000 gal storage tanks shown in Figure 8 are used in the nozzle, engine, and mixer cooling systems. All of the tanks were drained and dried and the lowest points in the system were used to verify the systems had been drained. A Lockout/Tagout process was implemented to prevent inadvertent activation of the internal heaters. On the 20,000 gal tank, all of the waterlogged, deteriorating insulation was removed and the structural parts were cleaned and painted as needed.

All of the rotating machinery in the facility, both electric-driven and diesel engine-driven, were drained, dried and stored in the facility pump house building.

The demineralized water system, based on a Reverse Osmosis (RO) unit, was put into longterm storage. This equipment was conditioned for a long-term storage period by injecting glycerin throughout the unit to prevent the growth of bacteria and to preserve the filter membranes.

4) Facility Crane: The Shepard-Niles facility crane was put into a standby state according to the 1974 document and with concurrence of the manufacturer. All gear boxes on the crane were drained and refilled with preservative oil. After refilling all gear boxes with preservative oil, the crane bridge and trolley were fully operated and parked. The hoist hook was lowered to the floor and raised to its Full-Up position. The movements were performed in an effort to distribute a coat 
of the preservative oil throughout each gear box. Finally, Lockout/Tagout procedures were applied to the crane power supply and a notice was installed on the crane control pendant that it was not to be used before refilling the gear boxes with normal lubricant.

5) Consolidation of HTF Support Assets: There are substantial assets associated with the facility including spare equipment and materials, facility hardware, assembly fixtures, tools, machines, facility nozzles, research hardware, electronics hardware, and computer equipment. Much of the HTF assets were stored throughout a variety of Plum Brook Station sites and warehouse buildings on an informal basis prior to the mothball effort. While the active facility staff knew where this equipment was located and was able to collect it as needed, loss of active staff will cause some of these informal arrangements to get lost with time. Therefore assets at the various sites around Plum Brook Station, some at risk for being excessed or discarded, were gathered into centralized, controlled locations. These HTF assets were documented and stored for the future facility staff. The facility tools, equipment, and hardware were placed in cabinets, toolboxes, or crates and relocated into storage bunkers on Plum Brook Station. Note that valuable equipment, tools, and machines for which other facilities had a critical need were loaned out with documented agreements for the return or replacement of these items. Electronics hardware and computers were removed, crated, and stored in the facility (including programmable logic controllers (PLC's), controls computers, data acquisition system, pressure transducers, heater vessel moisture detector, heater vessel oxygen analyzer, a servo valve actuator, and printers). Spare hardware and materials from the various sites around Plum Brook Station included graphite heater silicon tiles, steel for the Radiation Shutter Valve, ladder racks for cabling, a large variety of stainless steel piping, fittings, and facility-specific flange blanks. The three facility contoured nozzles and all corresponding diluents flanges were also stored in the facility or in another environmentally controlled storage building at Plum Brook Station. These are vital for free-jet testing and are exceedingly complex and valuable hardware that would be very difficult to replace.

6) Hydrocarbon Fuel Heater Loaned to NASA Langley Research Center: A new endothermic fuel heater system was installed in the HTF facility in 2005 in support of the ISTAR DirectConnect Combustor Experiment. This heater is capable of conditioning liquid hydrocarbon fuels to replicate the conditions of a flight engine heat exchanger in both temperature and composition. This system uses electrical power to cause an endothermic reaction of the hydrocarbon fuel; there are four similar fuel heaters in service in the United States. The HTF heater incorporated the best features and improvements from the other systems and is the largest in terms of fuel flow capacity.

At the request of NASA headquarters leadership, the NASA GRC HTF hydrocarbon fuel heater was loaned to NASA Langley for use at the 8-ft High Temperature Tunnel ( $8 \mathrm{ft} \mathrm{HTT}$ ). Specifically the following components were staged at the HTF and shipped to LaRC in September 2007: electrical power switch, the six 1-MW DC power converters, the fuel distribution valve pallet, the fuel heater coil pallet, spare inconel tubing and fittings, the DC feeder cables, the control skid for the fuel distribution panel, and all of the miscellaneous spare components for the system. This hardware remains an HTF asset but has been temporarily installed and validated at the $8 \mathrm{ft} \mathrm{HTT}$. This hardware has been adapted to some degree for integration into the $8 \mathrm{ft} \mathrm{HTT}$. However, it should be relatively straight forward to relocate this system back to HTF when required.

7) Safety and Security: It was recognized that once the facility was in mothball status it would be unstaffed and personnel would only be on-site periodically for the monthly safety walk-through or to perform maintenance/housekeeping if required. Access to the facility is limited to management and emergency personnel. There is an active security system in place at HTF which includes a surveillance video monitored by the security personnel. An access list of authorized 
personnel is maintained by Plum Brook Station security and only these individuals will be able to scan in (badge swipe) to access the facility and records of access will be retained. The plywood covering all first floor windows as previously discussed also provides added security. Hazardous chemicals were removed from the facility. All paper, cardboard, and other potential fire hazards were removed from the facility. The facility was cleared of office supplies and non-essential documents.

8) Preservation of Corporate Knowledge: As discussed earlier, it was assumed that HTF would remain in a mothball status for 10 years or more. It is likely that many of the current key personnel would be unavailable to support future facility reactivation and operation. Therefore, it was important to preserve this corporate knowledge by making sure that facility drawings, design documents, operating manuals and check lists, safety information, inventory lists, historical documents and information, and test reports were properly archived. During the mothball activity, all facility computer hard drives were imaged to compact disks. Facility drawings and papers were located to an HTF library area in the Plum Brook Station main office building. Facility drawings were also scanned into a centrally controlled electronic database.

\section{Sustainment Activities}

There has been a modest level of effort focused on facility sustainment (i.e., preserving and protecting) since the completion of the mothball activity in 2007. On a daily basis, station security personnel drive by the facility looking for any obvious problems. The heating system boiler has been maintained and the heat has been kept at a low setting to minimize any issues resulting from freezing temperatures or thermal cycling. There are periodic (monthly) checks and walkthroughs of the facility and buildings to identify any issues/problems. Inspections are made for any damage, leaks, or pest infiltration. The integrity of the nitrogen purge system is verified weekly by checking the nitrogen pressure and the supply trailer is changed out (or rail car recharged) when needed. The integrity of the screens and banding (preventing pest infiltration) are checked quarterly. Any repairs identified as needed are implemented as soon as possible. Repairs to date include replacement of the service air compressor, replacement of a failed relief valve on the hot water tank, and mitigation of a water line leak between the boiler house and the facility shop building. Grounds maintenance and janitorial services are also provided. This includes lawn mowing, snow removal, defoliation of stone and road surfaces; as well as dredging and re-grading the ditches annually. It is critical to maintain the exterior grounds at the facility to make sure there is adequate drainage and no back-up of water, snow, or ice into the facility.

\section{Tasks Required for HTF Reactivation}

The mothball activity as described has prepared HTF and its associated assets (including the graphite heater assembly and vessel, storage pressure vessels, synthetic air systems, tunnel circuit, test cabin, diffuser and exhauster) to be stored in the best-possible, documented, and known state. Never the less, significant work will be required to reactivate and bring HTF back to safe and reliable operation after this extended down time. Various screens, the plywood boards, and plating will be removed. The new facility operations crew will need to carefully and thoroughly review the facility drawings, design documents, operating manuals and check lists, safety information, inventory lists, historical documents and information, and test reports. This operations crew will also have to undergo significant training to operate the various HTF systems.

The graphite heater assembly and its many ancillary support systems are nearly "new" since only limited testing, at relatively benign conditions, has been conducted since the facility restoration/rebuild was completed in 2000 . The graphite heater assembly and vessel will be validated to verify the integrity of the cooling coils as well as no leakage from the vessel. The desired facility hot train, diluent flange, and nozzle configuration (free-jet or direct-connect) will be installed and checked for integrity. Most of 
the pressure vessels, propellant systems, and water systems will have to be recertified by the NASA Glenn Research Center Pressure Systems Office before operation. The recertification effort will include the graphite heater pressure vessel, the nitrogen rail car, the six oxygen supply bottles, the oxygen supply system, the nitrogen supply system, and the water supply systems.

The water systems will be brought back into service by reinstalling the rebuilt pumps and filling the supply tanks. The facility hydraulic system will be validated and operated. The synthetic air supply system including the nitrogen rail car and the oxygen bottles will be charged to working pressure. All pumps, both electrical and diesel, will be disassembled, rebuilt, reinstalled, and made operational. The synthetic air system components including valves, regulators, check valves, and flow meters will have to be validated and potentially rebuilt. Much of the electronics and computer equipment will be obsolete and will need to be replaced and reprogrammed. The useable electronics equipment will have to be validated and recalibrated. The facility crane may have to be disassembled and rebuilt. The facility tools, machines, and equipment will have to be moved back into the shop building.

It is estimated that an overall reactivation effort will require about a year. The graphite heater will be operated and validated; then a facility integrated systems test series will be conducted. The HTF test team and the NASA Plum Brook leadership believe that this facility has unique potential and value as the only "clean air" high Mach number capability in the nation. The team remains enthusiastic and prepared to bring HTF back into service whenever the facility is needed.

\section{Realities of Mothball Activity}

There were direct costs associated with the mothball task and there will be direct costs required to reactivate HTF. There are also intangible costs associated with idling a test facility. First, there is a loss of experience and expertise since many (most or all) key individuals will have moved to other projects or locations. The status of the facility in the test community is negatively impacted and the likelihood of the facility being selected for any future project is appreciably lower. The rapid evolution of electronics and computer systems necessitate the re-scope and installation of new data and controls systems as part of any restart effort. This includes a substantial amount of work needed to reassemble, checkout, reprogram, and recalibrate all the collective HTF systems. Most of these activities are typical of any new facility or test program. Therefore, the efforts and resources which will be required to bring HTF back into operation remain competitive with any effort to bring a new facility on-line. The effort will continue to grow in scope the longer the facility remains dormant, however, the infrastructure and vital systems will remain intact.

\section{Summary}

Throughout history, hypersonics research has experienced cycles where there are periods of intense activity followed by periods of little activity. In the early 1970s the Hypersonic Tunnel Facility (HTF) was configured to support the ground testing of the Hypersonic Research Engine (HRE). The HRE test provided an early demonstration of a supersonic combustion ramjet (Scramjet) concept. A rapid decline in hypersonics research followed not long after the HRE program and the HTF was mothballed for the first time in 1974. The facility was reactivated in 1990 on the footsteps of the National Aerospace Plane initiative. However, lack of maintenance and upkeep over the years led to a longer reactivation process than originally envisioned. Once reactivated, the facility was again used for hypersonic propulsion testing. This testing ended abruptly with the Radiation Shutter Valve failure in 1996. Following that failure, the graphite heater and many facility components were rebuilt. The current graphite heater system has experienced very little use at relatively benign conditions, therefore, the facility heater remains in excellent condition today.

In 2007, NASA elected to place the facility in a preserved mothball status to support future programs and projects. Lessons learned from the 1974 experience were directly applied to the 2007 mothballing process. The infrastructure is in good condition; all facility equipment is organized, inventoried, and put into protective storage; and all facility documentation has been brought up to date and preserved in an 
HTF library. This process ensures that future reactivation will be much more efficient than the previous experiences and that HTF remains available to support new projects. The scope of effort required for reactivation is not insignificant but is typical of a large-scale facility. The primary infrastructure and vital systems remain intact and protected. The team is confident that a reactivation will be accomplished efficiently and HTF will be again utilized for hypersonic propulsion testing in the future. 


\section{Appendix A.-NASA Procedural Requirements, NPR 8800.15A, Chapter 3.9.4}

3.9.4. Mothballed. A condition where a facility has been deactivated and appropriate maintenance measures have been taken to prevent deterioration of its vital or essential systems or placed in protective storage. Higher first year costs would be expected because of preparations for mothballing, but future annual costs should be significantly lower due to reduced maintenance and repair requirements. Total time to deactivate and then to reactivate the facility, including the mothballed period, is expected to exceed 12 months.

3.9.4.1. Utility systems and collateral equipment have been shut down and properly prepared for long term inactivation without significant deterioration. Selected systems should be kept in operation and inspected, such as cathodic protection systems.

3.9.4.2. Facility interior has appropriate environmental control to prevent significant deterioration.

3.9.4.3. The facility exterior envelope is inspected on a planned basis and work is accomplished as required to maintain the integrity of the exterior shell from the elements. The exterior of the facility shall also be kept in an aesthetically acceptable condition. 


\section{References}

1. Andrews, Earl H.; and Mackley, Ernest A.: NASA's Hypersonic Research Engine Project: A Review. NASA TM-107759, October 1994.

2. Thomas, Scott R.; Trefny, Charles J.; and Pack, William D.: Operating Capability and Current Status of the Reactivated NASA Lewis Research Center Hypersonic Tunnel Facility. AIAA-95-6146, April 1995, (NASA TM-106808).

3. Thomas, Scott R.; Perkins, H. Douglas; and Trefny, Charles J.: Mach 5 to 7 Performance Evaluation of a Rocket Based Combined Cycle Propulsion System at NASA LeRC HTF. NASA TM-107376, December 1996.

4. Woodling, Mark A.: Restoration of the Hypersonic Tunnel Facility at NASA Glenn Research Center, Plum Brook Station. NASA/TM-2000-209930, March 2000.

5. Lee, Jinho; and Krivanek, Thomas M.: Design and Fabrication of the ISTAR Direct-Connect Combustor Experiment at the NASA Hypersonic Tunnel Facility. NASA/TM-2005-213432, February 2005. 


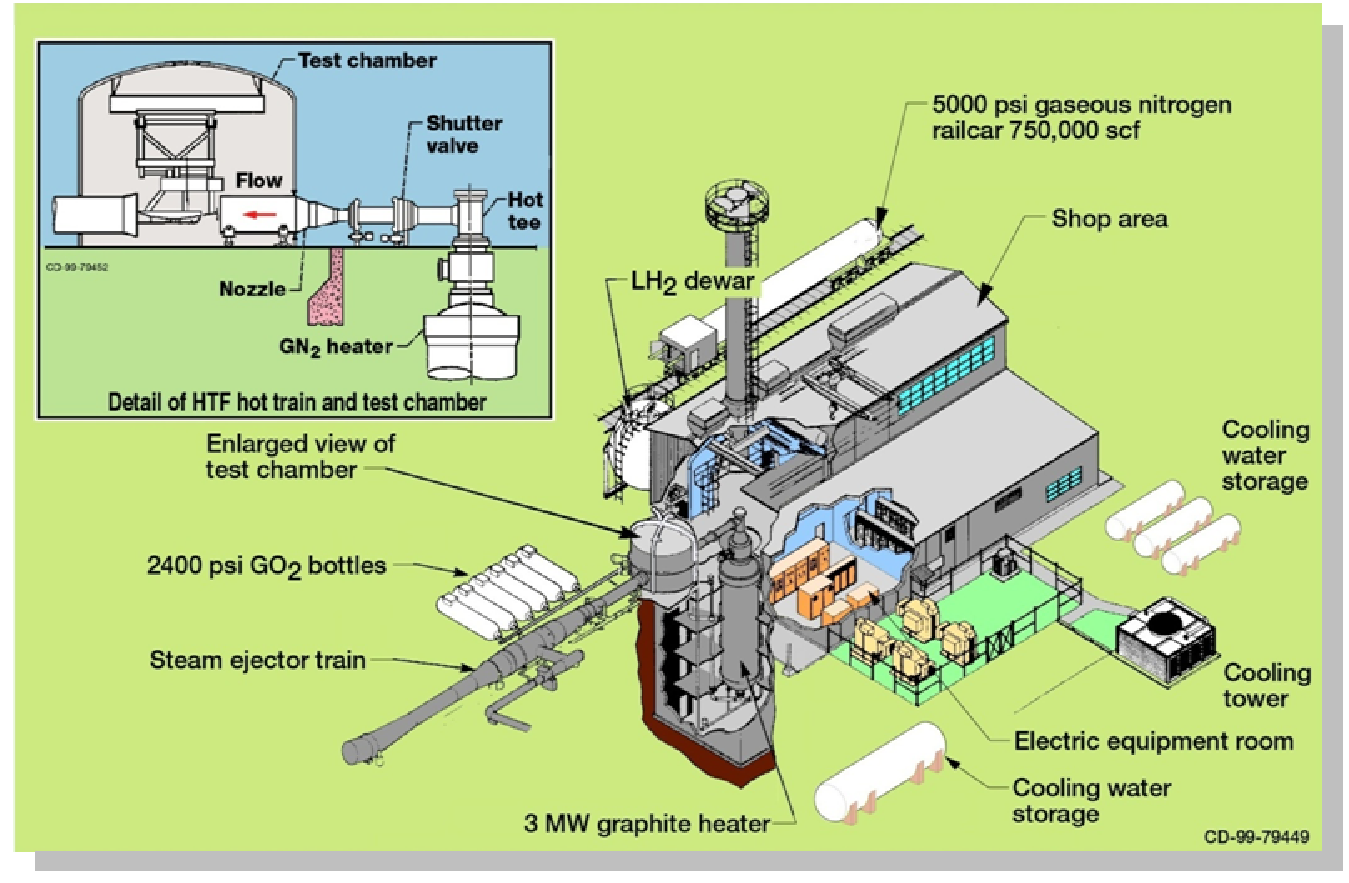

Figure 1.-HTF layout and support systems.

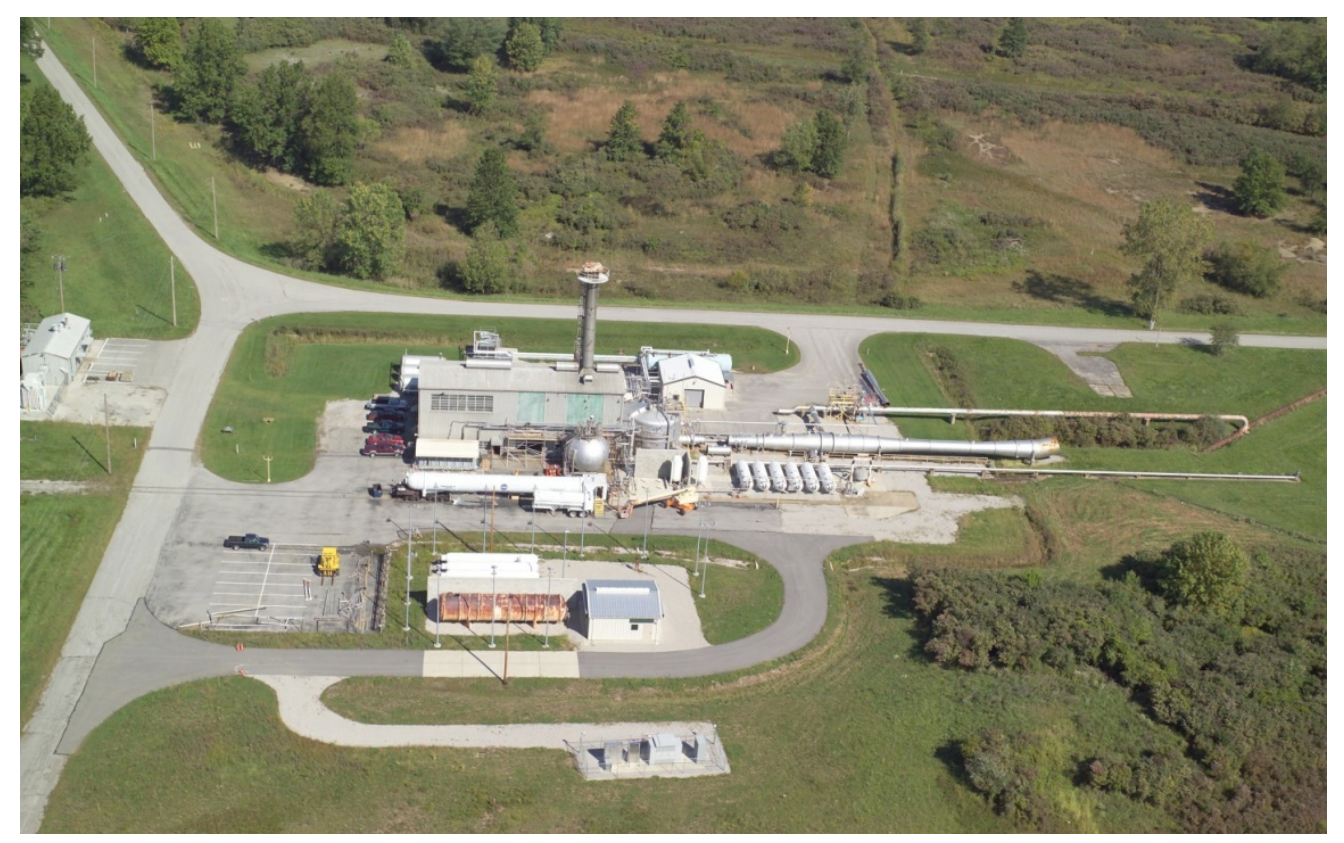

Figure 2.-Aerial view of the Hypersonic Tunnel Facility. 


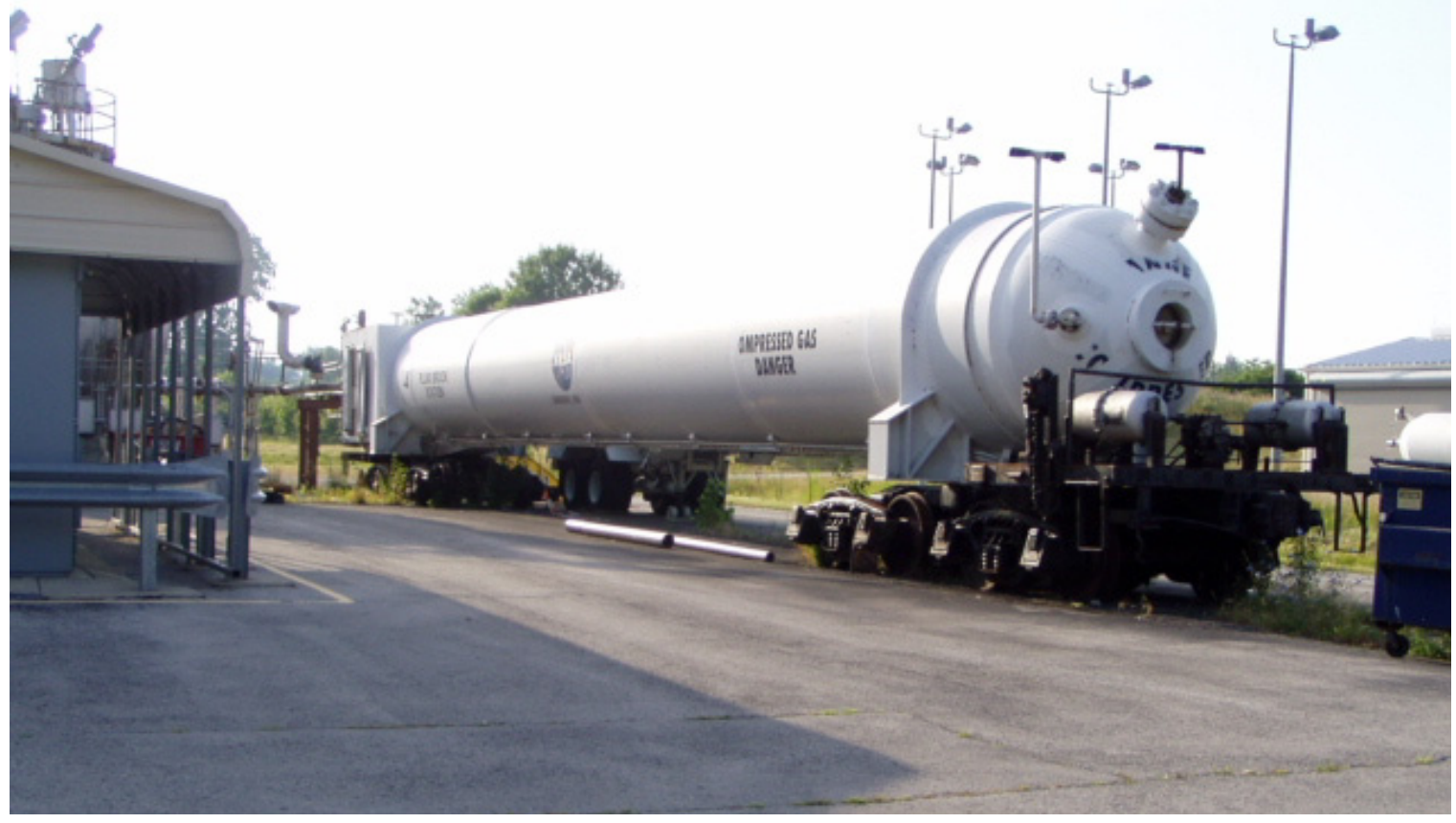

Figure 3.-HTF facility railcar providing gaseous nitrogen supply.

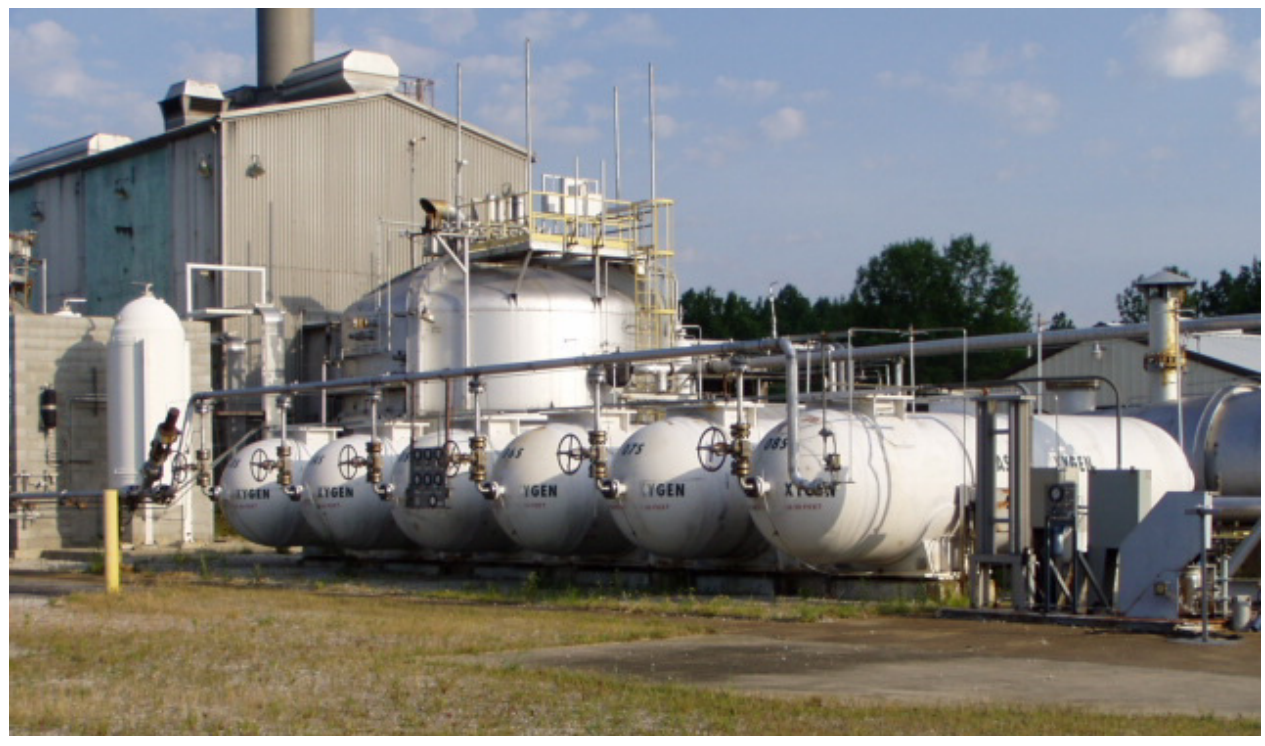

Figure 4.-HTF oxygen supply vessels. 


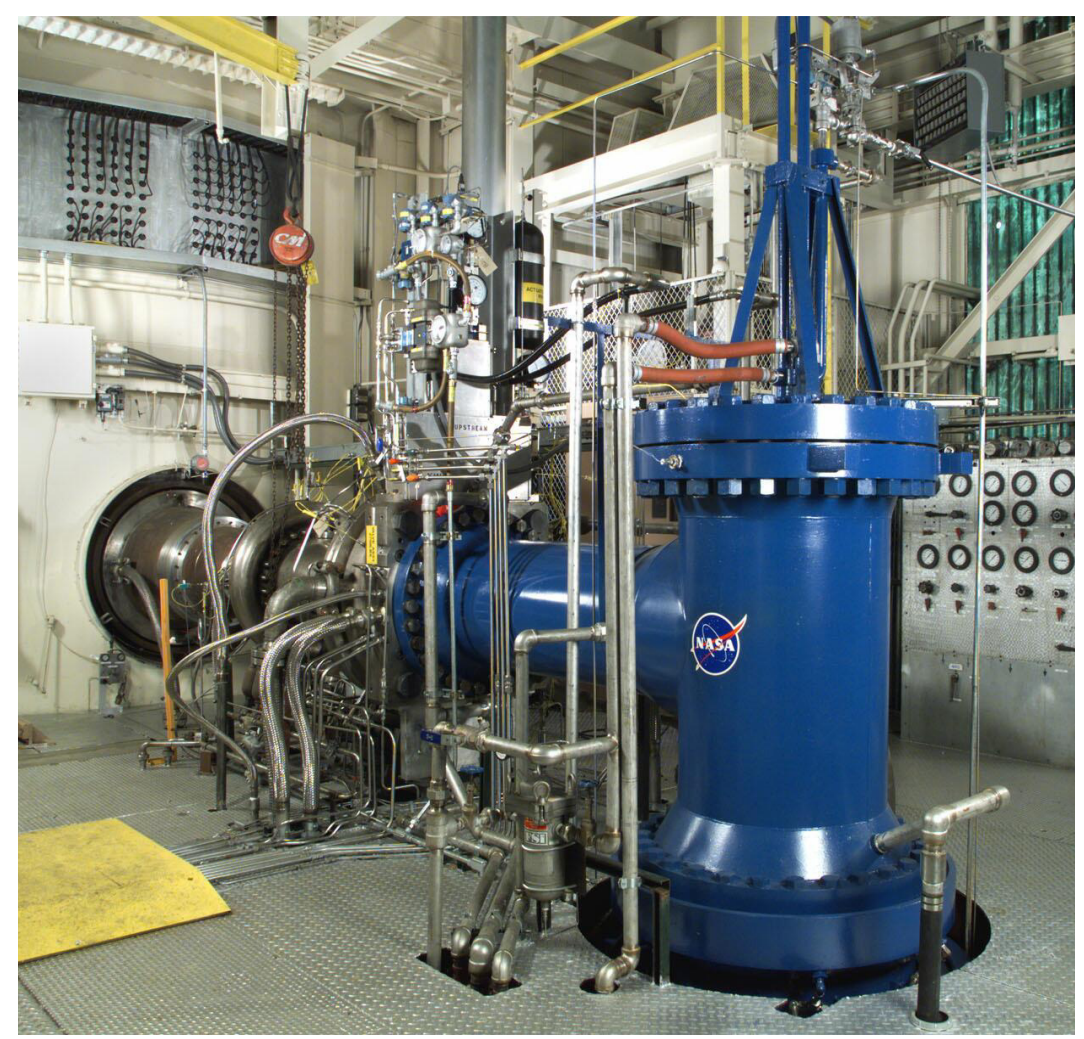

Figure 5.-Facility hot train supplied with hot nitrogen by graphite heater below floor.

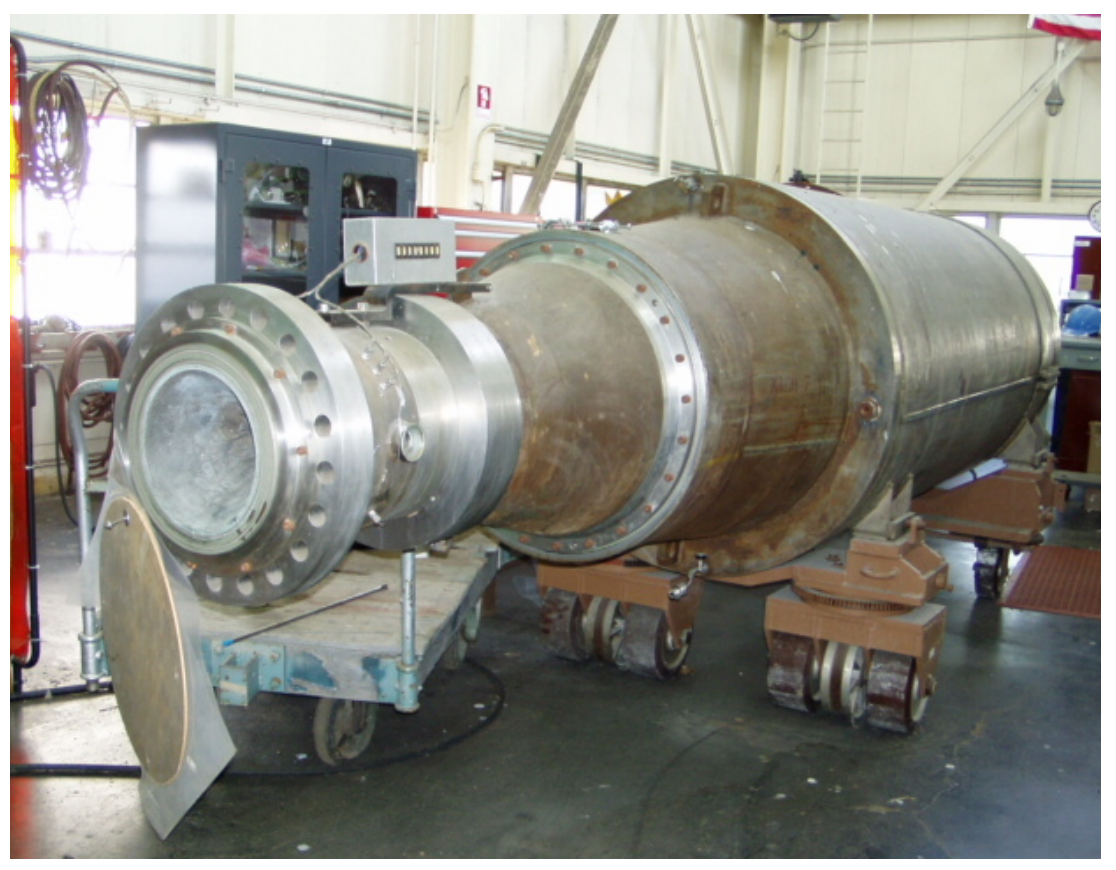

Figure 6.-HTF free-jet nozzle. 


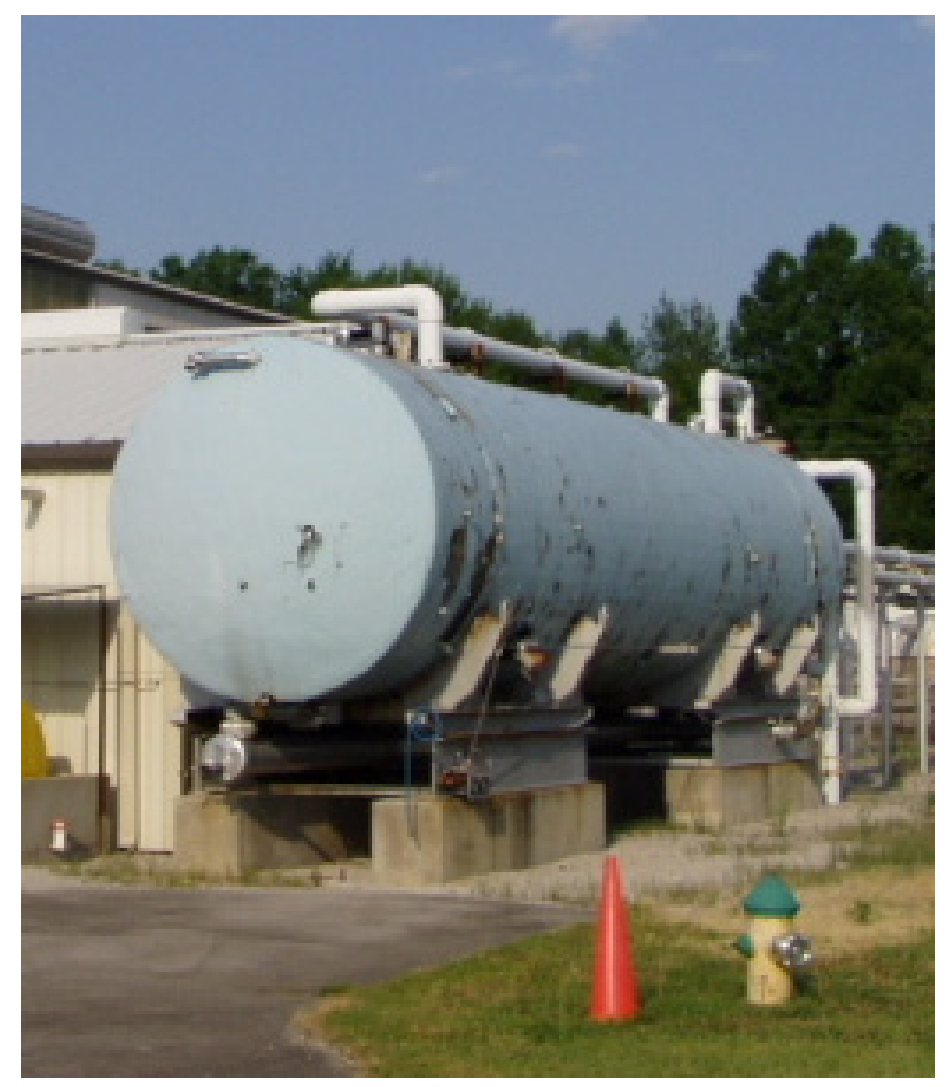

Figure 7.-Low pressure system cooling water supply tank (20,000 gal capacity).

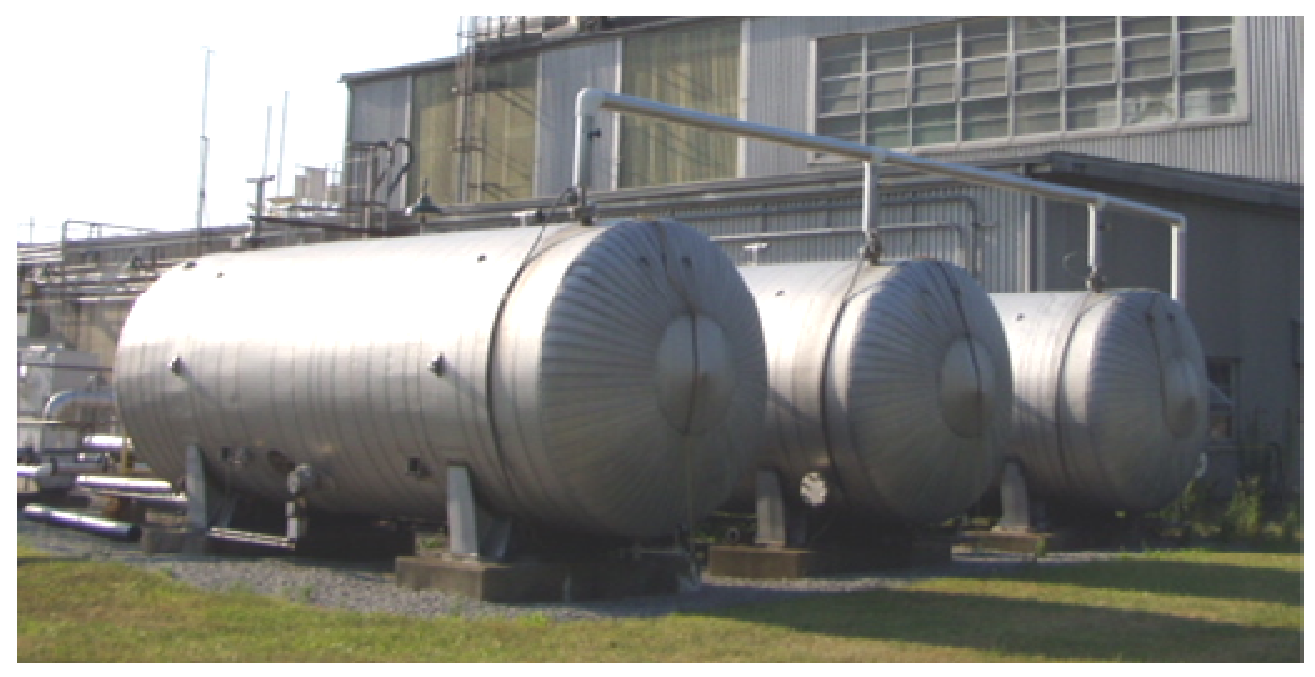

Figure 8.-High pressure system cooling water supply tanks (6000 gal each). 


\begin{tabular}{|c|c|c|c|c|c|}
\hline \multicolumn{5}{|c|}{ REPORT DOCUMENTATION PAGE } & $\begin{array}{l}\text { Form Approved } \\
\text { OMB No. 0704-0188 }\end{array}$ \\
\hline \multicolumn{6}{|c|}{ 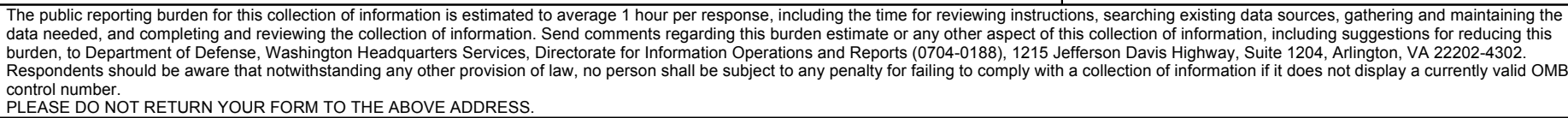 } \\
\hline \multicolumn{2}{|c|}{$\begin{array}{l}\text { 1. REPORT DATE (DD-MM-YYYY) } \\
01-12-2010\end{array}$} & \multicolumn{3}{|c|}{$\begin{array}{l}\text { 2. REPORT TYPE } \\
\text { Technical Memorandum }\end{array}$} & 3. DATES COVERED (From - To) \\
\hline \multirow{3}{*}{\multicolumn{5}{|c|}{$\begin{array}{l}\text { 4. TITLE AND SUBTITLE } \\
\text { The Mothball, Sustainment, and Proposed Reactivation of the Hypersonic Tunnel Facility } \\
\text { (HTF) at NASA Glenn Research Center Plum Brook Station }\end{array}$}} & 5a. CONTRACT NUMBER \\
\hline & & & & & 5b. GRANT NUMBER \\
\hline & & & & & 5c. PROGRAM ELEMENT NUMBER \\
\hline \multirow{3}{*}{\multicolumn{5}{|c|}{$\begin{array}{l}\text { 6. AUTHOR(S) } \\
\text { Thomas, Scott, R.; Lee, Jinho; Stephens, John, W.; Hostler, Robert, W., Jr.; Von Kamp, } \\
\text { William, D. }\end{array}$}} & 5d. PROJECT NUMBER \\
\hline & & & & & 5e. TASK NUMBER \\
\hline & & & & & $\begin{array}{l}\text { 5f. WORK UNIT NUMBER } \\
\text { WBS 599489.02.07.03.07.01 }\end{array}$ \\
\hline \multicolumn{5}{|c|}{$\begin{array}{l}\text { 7. PERFORMING ORGANIZATION NAME(S) AND ADDRESS(ES) } \\
\text { National Aeronautics and Space Administration } \\
\text { John H. Glenn Research Center at Lewis Field } \\
\text { Cleveland, Ohio 44135-3191 }\end{array}$} & $\begin{array}{l}\text { 8. PERFORMING ORGANIZATION } \\
\text { REPORT NUMBER } \\
\text { E-17540 }\end{array}$ \\
\hline \multirow{2}{*}{\multicolumn{5}{|c|}{$\begin{array}{l}\text { 9. SPONSORING/MONITORING AGENCY NAME(S) AND ADDRESS(ES) } \\
\text { National Aeronautics and Space Administration } \\
\text { Washington, DC 20546-0001 }\end{array}$}} & $\begin{array}{l}\text { 10. SPONSORING/MONITOR'S } \\
\text { ACRONYM(S) } \\
\text { NASA }\end{array}$ \\
\hline & & & & & $\begin{array}{l}\text { 11. SPONSORING/MONITORING } \\
\text { REPORT NUMBER } \\
\text { NASA/TM-2010-216936 }\end{array}$ \\
\hline \multicolumn{6}{|c|}{$\begin{array}{l}\text { 12. DISTRIBUTION/AVAILABILITY STATEMENT } \\
\text { Unclassified-Unlimited } \\
\text { Subject Category: } 09 \\
\text { Available electronically at http://gltrs.grc.nasa.gov } \\
\text { This publication is available from the NASA Center for AeroSpace Information, 443-757-5802 }\end{array}$} \\
\hline \multicolumn{6}{|c|}{ 13. SUPPLEMENTARY NOTES } \\
\hline \multirow{2}{*}{\multicolumn{6}{|c|}{$\begin{array}{l}\text { 14. ABSTRACT } \\
\text { The Hypersonic Tunnel Facility (HTF) located at the NASA Glenn Research Center's Plum Brook Station in Sandusky, Ohio, is the nation's } \\
\text { only large-scale, non-vitiated, hypersonic propulsion test facility. The HTF, with its 4-story graphite induction heater, is capable of } \\
\text { duplicating Mach 5, } 6 \text {, and } 7 \text { flight conditions. This unique propulsion system test facility has experienced several standby and reactivation } \\
\text { cycles. The intent of the paper is to overview the HTF capabilities to the propulsion community, present the current status of HTF, and share } \\
\text { the lessons learned from putting a large-scale facility into mothball status for a later restart. } \\
\text { 15. SUBJECT TERMS } \\
\text { Hypersonic wind tunnels }\end{array}$}} \\
\hline & & & & & \\
\hline \multicolumn{3}{|c|}{ 16. SECURITY CLASSIFICATION OF: } & $\begin{array}{l}\text { 17. LIMITATION OF } \\
\text { ABSTRACT }\end{array}$ & $\begin{array}{l}\text { 18. NUMBER } \\
\text { OF }\end{array}$ & $\begin{array}{l}\text { 19a. NAME OF RESPONSIBLE PERSON } \\
\text { STI Help Desk (email:help@sti.nasa.gov) }\end{array}$ \\
\hline $\begin{array}{l}\text { a. REPORT } \\
\text { U }\end{array}$ & $\begin{array}{l}\text { b. ABSTRACT } \\
\text { U }\end{array}$ & \begin{tabular}{|l|} 
c. THIS \\
PAGE \\
U \\
\end{tabular} & UU & $\begin{array}{l}\text { PAGES } \\
19\end{array}$ & $\begin{array}{l}\text { 19b. TELEPHONE NUMBER (include area code) } \\
443-757-5802\end{array}$ \\
\hline
\end{tabular}



